\title{
Accountability For Zakat, Infak/Sedeqah Management
}

\author{
Nurlinda Nurlinda ${ }^{1}$, Muhammad Zuhirsyan ${ }^{2}$ \\ \{nurlinda@polmed.ac.id ${ }^{1}$, zuhirsyan12@gmail.com $\left.{ }^{2}\right\}$ \\ ${ }^{1,2}$ Politeknik Negeri medan, Jalan Almamater No. 1 Kampus USU Medan, Indonesia
}

\begin{abstract}
The purpose of this research was analyzed the extent of the accountability in the management of zakat, Infak/sedeqah (ZIS) can raise the interest of Muzakki in channeling zakat, Infak/sedeqah. This research was qualitative study used the primary data of the questionnaire that was disseminated in 100 respondents of Islamic education institutions in Medan, as well as analyzed by using a descriptional analysis. The results found that the accountability of the Infak Zakat/sedeqah was still low. Low accountability of zakat, infak/sedeqah will raise the potential of fraud and reduces the trust of Muzakki which ultimately affects the low value of zakat, infak/sedeqah received.
\end{abstract}

Keywords: ZIS, Accountability, Governance, Fraud.

\section{Introduction}

People interest is low in raising the worship of Zakat, Infak/sedeqah (ZIS), but because of the awareness of Muslims that are not good at the importance of ZIS in the welfare of the people. In fact, Zakat is not only mandatory but also regulated in the Law of the Republic of Indonesia No. 23 of 2011 on Zakat Management [1]. Another Factor is not growing confidence in the management of Zakat managed by the state, where the manager of Zakat still has not been able to show its credibility as a mandate manager of Zakat. Zakat is one of the economic instruments and welfare of society that must be managed well [2], [3]. The potential zakat, Infak/sedeqah large and high level of benefits for the community certainly requires a guarantee that guarantees transparency and accountability in governance. It is certainly not separated from the enactment of Public Information Disclosure, since May 1, 2010. This law guarantees people's right to obtain public information, as well as to give responsibility to the public institutions to provide information to the community.

The experience of successful institutions raising funds voluntarily is generally due to the high public trust [4]. This high belief will certainly diminish when there is no transparency and accountability in the management of Zakat, Infak/sedeqah, because the Donator and the congregation also expects Zakat, Infak/sedeqah given can be held accountable. Currently the concept of trust Lillahi Ta'ala in which the recipient of zakat, Infak/sedeqah given a mandate to collect and manage the funds Zakat, Infak/sedeqah and The Giver believes completely irrelevant, because it is considered less Accountable and potentially cause fraud and defamation. Therefore, avoiding slander and suspicion, the accountability of zakat management, infaq/sedeqah must be held absolutely. Another consideration is because of community funds, Zakat must be managed responsibly (accountable). It is in accordance with the principle of zakat management which overall principle includes: 1) Islamic Sharia, 2) trusts, 3) benefits, 4) Justice, 5) legal certainty, 6) integrated, and 7) accountability [5]. Zakat Fund, infaq/sedeqah that is managed with good principles will be a mercy for the people in resolving economic problems and poverty alleviation [6][7]. 


\section{Review of Literature}

\section{a. Zakat Management Accountability}

The responsibility of the accountability is a duty to report and be responsible for the success or failure of implementing the Organization's mission in achieving the results set before, through the media Accountability undertaken periodically [8], while Mohammad et al. states accountability consists of three types 1) financial accountability where accountability includes Financial statements consisting of revenues/receipts, storage, and expenses; 2) Accountability of benefits, where accountability covering related outcomes of achievement in accordance with the procedure and the most important achievement of the objectives is effectiveness and 3) accountability of procedural where accountability related to the importance of implementation procedures by considering the principle of ethics, morality and legal certainty [9][10].

Highlighting the accountability in Zakat management, Ram Al Jafri Saad states that the accountability or accountability of zakat management is not merely to the payer of zakat (Muzaki) or the recipient of zakat (Mustahik ) [11], but is a network of accountability to zakat payers, the recipients of zakat, supervisory institutions, and accountability to Allah SWT. This form of accountability cannot be dismantled from the general Islamic teachings. People are always held accountable for their actions and behaviour.

Criteria used to see how adequate accountability of zakat management, Infak/sedeqah on Islamic education institutions in Medan City using reference from Sugiyono that are 1) $0.00-0.199$ category very low; 2) $0.20-0.399$ low category; 3 ) $0.40-0.599$ category quite strong; 4 ) $0.60-0.799$ strong category; 5) $0.80-$ 1,000 category is very strong [12].

Zakat issued is collected from the innovation to be channeled to the groups that have been specified in the letter At Taubah verse 60 which reads "Indeed, Zakat is only for people who are poor, needy, amil zakat, Was deprived of his heart (converts), to (liberate) the servant of the Sahaiah, to (free) the indebted, for the way of God, and the man on his way, as a duty of God. Allah knows, he hears "(Foundation of Translation organizer/Commentators of the Qur'an, 2000)"[13]. To control transparent and accountable empowerment programs need to be set operational standard procedure [2].

\section{b. Islamic Educational institutions}

Islamic education in its development in Indonesia, among others, marked by the emergence of various educational institutions gradually, ranging from the very simple, to the stages that have been numbered Modern and complete [14]. The Islamic educational institution has played its role in accordance with the demands of society and its era. The development of these institutions has attracted the attention of experts from both inside and outside the country to conduct scientific studies in a comprehensive. Now, there are many research works of experts who inform about the growth and development of Islamic educational institutions. The goal is to enrich the knowledge of Islamic education in the future, as well as a reference material and comparison for the managers of Islam. This is in line with the generally adopted principle of Indonesian Islamic society, which is to maintain a tradition of the past that is still good and take a good new tradition again. In this way, the development efforts of the Islamic educational institutions will not be absorbed from the roots of the cultured radically.

\section{Research Methodology}

The population of this research is the entire Islamic education institution in Medan. The study spread as many as 100 questionnaire to staff respondents to the financial institutions. The data analyzed using descriptive analysis.

\section{Discussion And Results}

\subsection{Financial accountability}

Financial accountability is an accountability that includes financial statements consisting of income/acceptance, storage, and expense. Management of zakat that emphasizes accountability, will give positive signal for the Muzakki to continue to feed his property to the path of Allah SWT by channeling Zakat, 
Infak/sedeqah. The current phenomenon is the rise of accountable governance in the entire organization is no exception to the governance of zakat, Infak/Sedeqah. The demands of accountability primarily require transparency and providing information to the public in order to fulfill the public rights [15]. Accountability is the obligation of the trustees to give accountability, present, report and disclose all activities and activities that are the responsibility of the manager to the Trustee (Principal). The management of Zakat, inaccountable/sedeqah that there is accountability and accountability of legal, process accountability, program accountability and accountability of the policy would certainly be the managing of zakat management, Infak/ sedeqah will be better .

The result show that financial accountability in accepting, recording and posting Zakat, Infaq/sedeqah received. Out of the 5 instrument statements filed on average the highest respondents answer of 22 or $40.7 \%$ replied to the statement "the passage that receives the ZIS, booked ZIS and kept the ZIS done by the same officer". This shows that ZIS management is not good, as this data shows the weakness of internal control especially on elements of surveillance. Ideally, in the governance there must be a separation of functions between the receiver function, the registrar and the depository so that the elements will be formed adequate supervision. When all these activities are done by the same person, it will be difficult to supervised because of Zakat, Infak/sedeqah received is the most liquid asset that is easily distorted if the control is weak. However, from 54 Islamic institutions, there are 9 Islamic educational institutions or $16.7 \%$ do not perform the procedure. It will be very risky for the Islamic education institution to supervise the amount of zakat, Infak/Sedeqah received from Muzakki. From this table only 7 or $13.0 \%$ of Islamic education institutions have fulfilled the financial ZIS governance.

\subsection{Accountability Benefits}

Benefits accountability is a responsibility that includes related to the achievement of objectives in accordance with the procedure and the most important of such achievement is the effectiveness of the distribution of zakat, Infak/sedeqah. Related accountability benefits are measured by the extent to which the respondent provides answers to the following questions:

"Do you think that the channeling of Zakat, Infaq, sedeqah that was carried out was right on target?"

On that question, 54 respondents responded quite well. The opinion that the Islamic education institution has channeled zakat, Infak/Sedeqah on the right target represented by 39 respondents or $72.22 \%$, while as many as 15 respondents or as much as $27.78 \%$ responded to the untimely seam. These results indicate that the management of zakat, Infak/Sedeqah still need to be improved so that the distribution can be more precise target. Respondents ' responses to the following questions:

"How is the distribution of Zakat, Infak/sedeqah according to you?"

The respondent's response is that the distribution of zakat, Infaq/Sedeqah is done after a) correct data collection, B) Mustahik must comply, c) the distribution is conducted directly without the intermediary of others or the distribution of zakat can be done through the institution , d) Distribution is clear and transparent in order not to happen unfamiliarity, E) to select the recipient of zakat strictly and ensure that there is no mustahik relationship with Muzakki and the management of Zakat. Respondents stated that still not maximized in the fund distribution at Mustahiq still needs to be repaired and improved. As for the mechanism, respondents responded that zakat, Infak/Sedeqah must be managed through a special body, channeling zakat, Infak/Sedeqah by transfer to be more accountable, for Infak/Sedeqah collection can be through a sedeqah box. Related to the supervision of respondents gave the response that the Islamic educational institutions should be given coaching in the distribution of zakat, Infak/sedeqah, and managed professionally by placing managers who have the understanding, ability and sufficient expertise about the governance of Zakat, Infak/sedeqah. Besides the management of Zakat, infaq alms on Islamic education institutions still need assistance and supervision in order to be carried out in accordance with the procedures and rules of Sharia.

\subsection{Procedural accountability}

Accountability procedural is an accountability related to the importance of implementation procedures by considering the principle of ethics, morality and legal certainty. Table 2 shows the data related to the process performed by the Zakat,Infak/sedeqah when receiving ZIS from Muzakki. Ideally the ZIS received must be a formal numbered receipt and then proceed to request a leadership authorization to be recorded in a good 
bookkeeping, then channeled and announced. However, if the ZIS has not been channeled it is stored in adequate storage such as a safe or using Sharia banking services.

Data in table 2 of the statement of points 1 and 4 overall is not worth 54 (maximum respondents). This indicates that the accountability of the process is not running adequately, where the average value is below $50 \%$. Precisely on the fifth statement "Infak/sedeqahreceived, immediately stored and the end of the period is calculated and then recorded" the respondent answered more than 50\%, which is 29 Responde or $54 \%$. It can be concluded that the ZIS maintainers have not understood the concept of adequate accountability. And this will certainly pose the risk of lack of the ZIS acceptance. When the institution has implemented the accountable ZIS governance indicates that the agency has transparently disclosed about the ZIS in the institution.

Data processing demonstrates from several dimensions of accountability ranging from financial accountability and accountability to benefits, procedural accountability, there are two dimensions of accountability in the low category of financial accountability and procedural accountability, while the accountability of the benefits of data-processing results shows a reasonably good value. The element that reveals the accountability of one of them is that transparency shows have not looked good because the results of data processing are on "low" criteria. These results suggest that there is no culture to process, record, report and disclose the acceptance of zakat, Infak/accountable accountably. Theoretically if the entity has implemented accountable management will increase the trust of the zakat, Infak/sedeqah. The more accountable the management will have an impact on the increasingly trusting Muzakki in submitting zakat. Another allegation we concluded that the Islamic education institution in the city of Medan does not do the voting process of zakat, so that teachers and employees are not motivated to worship voluntarily count and surrender ZIS to the relevant agencies. The collection of qualitative data on ZIS's collection ability can be concluded that from 54 respondents 46 respondents or $85.19 \%$ stated it was capable, while 8 respondents or as of $14.81 \%$ said it could not afford.

This respondent's belief can be used as a measuring instrument that ZIS potential can be collected by involving the Islamic educational institution as an institution that collects zakat, Infak/sedeqah, while related to the ability of the Islamic educational institution in ZIS managed to manage the response that from 54 respondents 48 respondents or $88.89 \%$ said that the institution is able to manage zakat, Infaq good sedeqah from the profession Zakat teachers and employees and Infaq/sedeqah from outside especially from the parents. However, there are 6 respondents or $11.11 \%$ stating that the Islamic educational institution is incapable of managing zakat, Infak/sedeqah. There is hope from respondents that the Islamic education institution is able to be a model in collecting and managing Zakat, Infak/sedeqah so as to be channeled mainly to improve the welfare of the people who work on the Islamic Educational institution Especially and if excess is able to improve the welfare of the Islamic community outside the Islamic educational institutions. The results of the respondents response showed that the Islamic Education Institute was actually not ready in managing Zakat, Infak/sedeqah. This disagreement can be caused by a lack of knowledge about the governance of zakat, infak/sedeqah accountability. The provision of socialization, training will be a strong capital for the Islamic education institution in applying the governance accountable. Further respondents responded to the benefits and distribution of ZIS. Respondents responded quite well the results showed that the management of zakat, Infak/sedeqah still need to be further improved so that the distribution can be more precise target.

The action who will be done is by conducting the identification of the beneficiary of zakat, Infak/sedeqah. The type of zakat channeled and needed for Mustahik is not just channeled. So that the results that want to be achieved is improving the welfare of the Islamic community can be achieved adequately. This research is further strengthened by the response of the respondent stating that the distribution of zakat, Infaq/Sedeqah done after a) correct logging, B) Mustahik must comply, c) The distribution is carried out directly without the intermediary of others or the channeling of zakat can be done through institutions, D) distribution is clear and transparent in order not to happen unfamiliarity, E) to check the recipient of zakat strictly and ensure that there is no connection Mustahik with Muzakki and the management of Zakat.

Respondents stated that the ZIS distribution mechanisms are still not maximized and ZIS must be managed through a special body, channeling ZIS through the transfer process to be more accountable. About the ZIS collection can be through a sedeqah box. Related to the supervision of respondents gave the response that the Islamic educational institutions should be given coaching in the ZIS distribution and ZIS professional management by placing staff who have sufficient understanding, ability and expertise about ZIS governance. In addition to the ZIS management of Islamic education institutions still need assistance and supervision in order to be carried out in accordance with sharia procedures and rules. 


\section{Conclusion}

The results of the study found that out of all three dimensions, namely, financial accountability, benefits accountability and accountability procedural found that in general accountability levels are still low. Judging from the transparency also shows a low transparent level

\section{References}

[1] Undang-Undang Nomor 23, Tentang Pengelolaan Zakat. 2011.

[2] I. Andriyanto, "Pemberdayaan Zakat dalam Meningkatkan Kesejahteraan Umat," J. Zakat dan Waqaf “ Ziswaf"Ziswaf, vol. 1, no. 2, pp. 227-248, 2014.

[3] A. B. S, “Zakat sebagai Instrumen Pembangunan Ekonomi Kesejahteraan Umat,” J. Stud. Ekon. dan Bisnis Islam, vol. 1, no. 2, pp. 74-89, 2016.

[4] A. K. Syafa'at and L. A. F. Ekaningsih, "Potensi Zakat, Indaq, Shodaqoh Pada Badan Amil Zakat Nasional (BAZNAS) di Kabupaten Banyuwangi," Inferensi, J. Penelit. Sos. Keagamaan, vol. 9, no. 1, pp. 25-46, 2015.

[5] A. Subekan, "Potensi Zakat Menjadi Bagian Keuangan Negara," J. Huk. dan Syariah, vol. 7, no. 2, pp. 105-126, 2016.

[6] M. A. Athoillah, "Zakat untuk Kesejahteraan Bangsa,” Media Syariah, vol. XVI, no. 1, pp. 491-576, 2014.

[7] I. Mubarokah, I. S. Beik, and T. Irawan, "Dampak Zakat terhadap Kemiskinan dan Kesejahteraan Mustahik (Kasus: BAZNAS Provinsi Jawa Tengah),” J. Al-Muzara'ah, vol. 5, no. 1, pp. 37-50, 2017.

[8] Mardiasmo, Otonomi dan Manajemen Keuangan Daerah. www.kajianpustaka.com (04 Maret 2017), 2017.

[9] Nurlinda, “Akuntabilitas Pengelolaan Keuangan Desa,” J. Ris. Akunt. Keuang., vol. 6, no. 1, pp. 17051714, 2018.

[10] R. Fajri and E. Setyowati, “Akuntabilitas Pemerintah Desa Pada Pengelolaan Alokasi Dana Desa (ADD) (Studi pada Kantor Desa Ketindan, Kecamatan Lawang, Kabupaten Malang),” J. Adm. Publik, vol. 3, no. 7, pp. 1099-1104, 2015.

[11] R. Al, J. Saad, M. A. Aziz, and N. Sawandi, "Islamic accountability framework in the zakat funds management," Procedia - Soc. Behav. Sci., vol. 164, no. 2014, pp. 508-515, 2014.

[12] Sugiyono, Metode Penelitian Kuantitatif, Kualitatif, dan R\&D. Bandung: Penerbit Alfabeta., 2016.

[13] Departemen Agama Republik Indonesia, Alquran dan Terjemahannya. Jakarta, 2002.

[14] Akhirudin, "Lembaga Pendidikan Islam di Indonesia," J. Tarbiya, vol. Vol 1, no. No. 1, 2015.

[15] Mardiasmo, Akuntabilitas Sektor Publik, IV. Yogyakarta: C.V Andi Offset, 2009. 